Article

\title{
Copy Number Variation of Transposable Elements in Thinopyrum intermedium and Its Diploid Relative Species
}

\author{
Mikhail G. Divashuk ${ }^{1,2}\left(\mathbb{D}\right.$, Gennady I. Karlov ${ }^{1,2} \mathbb{D}$ and Pavel Yu. Kroupin $1,2, * \mathbb{C}$ \\ 1 Laboratory of Applied Genomics and Crop Breeding, All-Russia Research Institute of Agricultural \\ Biotechnology, Moscow 127550, Russia; divashuk@gmail.com (M.G.D.); karlov@iab.ac.ru (G.I.K.) \\ 2 Centre for Molecular Biotechnology, Russian State Agrarian University-Timiryazev Agricultural Academy, \\ Moscow 127550, Russia \\ * Correspondence: pavelkroupin1985@gmail.com
}

Received: 3 October 2019; Accepted: 17 December 2019; Published: 21 December 2019

\begin{abstract}
Diploid and polyploid wild species of Triticeae have complex relationships, and the understanding of their evolution and speciation could help to increase the usability of them in wheat breeding as a source of genetic diversity. The diploid species Pseudoroegneria spicata (St), Thinopyrum bessarabicum $\left(\mathrm{J}^{\mathrm{b}}\right)$, Dasypyrum villosum $(\mathrm{V})$ derived from a hypothetical common ancestor are considered to be possible subgenome donors in hexaploid species Th. intermedium $\left(\mathrm{J}^{\mathrm{r}} \mathrm{J}^{\mathrm{vs}} \mathrm{St}\right.$, where indices $\mathrm{r}, \mathrm{v}$, and $\mathrm{s}$ stand for the partial relation to the genomes of Secale, Dasypyrum, and Pseudoroegneria, respectively). We quantified 10 families of transposable elements (TEs) in P. spicata, Th. bessarabicum, D. villosum (per one genome), and Th. intermedium (per one average subgenome) using the quantitative real time PCR assay and compared their abundance within the studied genomes as well as between them. Sabrina was the most abundant among all studied elements in P. spicata, D. villosum, and Th. intermedium, and among Ty3/Gypsy elements in all studied species. Among Ty1/Copia elements, Angela- $A$ and WIS- $A$ showed the highest and close abundance with the exception of $D$. villosum, and comprised the majority of all studied elements in Th. bessarabicum. Sabrina, BAGY2, and Angela-A showed similar abundance among diploids and in Th. intermedium hexaploid; Latidu and Barbara demonstrated sharp differences between diploid genomes. The relationships between genomes of Triticeae species based on the studied TE abundance and the role of TEs in speciation and polyploidization in the light of the current phylogenetic models is discussed.
\end{abstract}

Keywords: transposable elements; genome evolution; polyploidization; copy number variation; Pseudoroegneria; Dasypyrum; Thinopyrum

\section{Introduction}

Transposable elements (TEs) are ubiquitous components of many studied eukaryotic genomes that are able to move around and proliferate within the host genome. The TE abundance ranges from $10 \%$ to $12 \%$ in the Arabidopsis thaliana and $70 \%$ to $80 \%$ in maize, barley, and wheat genomes [1-8]. TEs are categorized into the following two classes: class I (retrotransposons) that transpose via an element-encoded mRNA intermediate produced from a promoter in a long terminal repeat (LTR retrotransposons) or from an internal promoter (non-LTR retrotransposons) that is reverse-transcribed into DNA and integrated elsewhere in genome ("copy and paste"); and class II (DNA transposons) that transpose via DNA that is excised and reinserted into the host genome ("cut and paste"). Although the genomes of flowering plants have a rich collection of both TE classes, class I LTR retrotransposons are predominate in plant genomes, with prevailing families of Ty1/Copia and Ty3/Gypsy retrotransposons, 
determining the size of most plant genomes including monocots and dicots [9-17]. Among Class II TEs only five superfamilies have been found in plant genomes (CACTA, Mutator, PIF/Harbinger, hAT, and Tc1/mariner) [18,19].

TEs make a considerable contribution to evolutionary processes and speciation being one of the major forces in plant genome evolution [20-23]. Transposable elements affect the fitness of the host through altering expression or function of protein-coding genes. It may give rise to new alleles or even new gene formation and transcriptome variation, illegitimate recombination and chromosome breakage [24-31]. The hypothesis of 'genetic shock' suggests that interspecific hybridization may be accompanied by the proliferation or elimination of TEs leading to dramatic changes in a hybrid genome [32]. The dynamics of TEs, in particular, LTR retrotransposons, is supposed to be the main cause of plant genome size alterations on the evolutionary time scale [12,33-37]. Recent findings have shown that TEs are population-specific and apparently involved in population divergence and speciation at the diploid level [38-40].

In ancient allopolyploids and experimentally derived synthetic interspecific hybrids, the copy number of TEs is usually higher in comparison to their related diploid species increasing the plant genome size that is considered in some cases to be the result of 'genome stresses' [41-45]. However, depending on the TE family and plant species, the polyploidization may also be accompanied by the absence of changes in the TE copy number or even in the TE elimination [28,43,46-48]. Polyploidization and interspecific crosses have been shown to result in serious epigenetic changes that may involve modifying DNA methylation status of TE's promoters [49,50]. A general trend seems to be the demethylation of TEs in newly formed allopolyploids that may be followed by returning to a methylation state similar to parental [51-53]. However, the observed methylation alternations depend on a unique TE, species genome and hybrid generation $[28,42,50,53,54]$.

Among plant species, one of the highest TE abundance is observed in Triticeae species such as in oats $(65 \%)$, rye $(72 \%)$, wheat $(80 \%)$, and barley $(81 \%)$ [17,55-57]. Genetic and epigenetic dynamics of TEs have been thoroughly studied in wheat as compared with its genome donors ("evolutionary scale") and in newly formed synthetic allopolyploids as compared with parental species ("revolutionary scale") [28,52-54]. The study of the genomes of wheat relatives could help to find out the basis of Triticeae speciation and allopolyploidization, as well as the relationships between species including wild grasses. Among a huge variety of wild Triticeae species, closely related genomes St, J, and V are of particular interest as they can be found at different ploidy levels, namely, in diploids such as Thinopyrum bessarabicum (Savul. \& Rayss) Á.Löve $\left(2 \mathrm{n}=2 \mathrm{x}=14, \mathrm{~J}^{\mathrm{b}}\right)$, Dasypyrum villosum (L.) Coss. \& Durieu ex P. Candargy $(2 n=2 x=14, V)$, and Pseudoroegneria spicata (Pursh) Á.Löve $1980(2 n=2 x=14$, St), and presumably participated in the speciation of Thinopyrum intermedium (host) Barkworth \& D.R. Dewey $(2 n=6 x=42)$ with genomic composition J $J^{\mathrm{r}} \mathrm{J}^{\mathrm{vs}} \mathrm{St}$, where J stands for the proximity to the genome of Th. bessarabicum $\left(\mathrm{J}^{\mathrm{b}}\right)$ or Th. elongatum $\left(\mathrm{J}^{\mathrm{e}}\right)$, and indices $\mathrm{r}, \mathrm{v}$ and $\mathrm{s}$ demonstrate the presence of DNA repeats character for Secale (R genome), Dasypyrum (V genome) and Pseudoroegneria (St genome) species [58-63]. Additionally, the genomes of these species carry valuable genes that confer resistance to adverse environmental conditions (salinization, drought, frosts etc.), many of which have been successfully transferred to wheat via wide hybridization [64-67].

The study of TEs in wild Triticeae species could help to untangle the evolutionary relationship between St, J, and V genomes [68-70]. Although in all plant genomes, the majority of TEs is represented by LTR retrotransposons and the abundance of particular LTR families is highly variable among even closely related species [71]. The comparison of the TE's abundance between the genomes of diploids and subgenomes in polyploids is of great interest as it may help to understand the speciation after the divergence from the common ancestor and the contribution of a particular genome in polyploid formation. Different molecular techniques ranging from conventional PCR to digital PCR as well as bioinformatic approaches have been applied to study TE's polymorphisms that enable rapid and accurate identification of different TE's insertions in the genome that helps to estimate genome modifications during evolution [72]. Recently, we demonstrated different 
abundance of Ty3/Gypsy centromeric retrotransposon on the individual chromosomes of particular subgenomes of Th. intermedium that may be the result of possible burst of this retrotransposon during allopolyploidization [73]. Moreover, the knowledge of transposable elements will provide the basis for the development of new PCR and cytogenetics markers that will facilitate the introgression of agronomically valuable traits into wheat genome [74,75].

The abundance of transposable elements (TEs) can be assessed using different approaches [72]. The computational analysis using NGS sequencing data have been successfully applied in Triticum, Hordeum and Secale studies $[27,31,56,76]$. However, such approach is limited due to the complex organization of TEs and the assembly problem caused by huge TE redundancy and may not be accurate for genomes that have not been successfully assembled [77]. The dot-blot and Southern hybridization are time and labor consuming procedures $[78,79]$ while fluorescent in situ hybridization provide only qualitative comparison between genomes $[79,80]$. Real-time quantitative polymerase chain reaction ( $\mathrm{qPCR}$ ) is a powerful tool that enables an accurate estimation of copy number in genomes $[28,39,42,52,73,81]$. The data on relative TE abundance obtained using qPCR assay was shown to be very similar and comparable with data obtained from genome sequences analysis that demonstrates the efficiency of the qPCR approach $[28,81]$.

The aim of this paper is to assess the interspecific variation of LTR retrotransposons and DNA transposon in polyploid Th. intermedium and its candidate progenitors, diploids P. spicata, Th. bessarabicum, and D. villosum using the $\mathrm{qPCR}$ assay.

\section{Results}

We calculated the quantity of the TEs within genomes in P. spicata $(\mathrm{St})$, Th. bessarabicum $\left(\mathrm{J}^{\mathrm{b}}\right)$, D. villosum $(\mathrm{V})$, and Th. intermedium $\left(\mathrm{J}^{\mathrm{r}} \mathrm{J}^{\mathrm{vs}} \mathrm{St}\right.$ ) using normalization of the target sequences to the reference gene VRN1. It should be noted that there are differences in the size and nucleotide content of the fragments amplified from different TEs in one species. As a result, slightly different level of Eva Green ${ }^{\circledR}$ binding with DNA is possible even if the abundance of different TEs is the same. And, as a consequence, slightly different level of fluorescence can be observed even at the same copy number. Therefore, we cannot consider this data as precise absolute values of TE copy number when comparing TE abundance within the studied genomes. However, since the amplicons of all the studied TEs have very similar size, we may reliably use this data to compare the abundance of different TEs between each other within the genomes of the studied species.

Besides, we calculated the normalized relative TE's quantity (NRQ) to compare genomes between each other. The divergence in TEs sequences among species during evolution and speciation could have affected both primer binding sites of the qPCR amplicon and sequences between them (inner regions). In the first case, nucleotide polymorphisms could result in primer mismatch and, eventually, imperfect amplification. This issue is addressed by the primer efficiency estimation and a corresponding coefficient is included in equation of the TE's quantity (Table S1). In the case if dramatic changes in nucleotide sequences have happened in the inner region, then the melting temperature of the fragment of the same TE amplified at qPCR in different species would be significantly different. Additionally, if the TE divergence has occurred within species genome, two different melting temperatures would have observed. In our experiments, only primers the produced amplicons with single peak at the melting curve and similar melting temperature of the same TEs between different species were chosen (Figure S1, Table S2). Moreover, using a given primer pair we may amplify the pool of different variants of the same TE that are conservative in primer binding site and thus to trace the quantitative differences between genomes.

\subsection{TE Copy Number Variation within Genomes}

As a result of qPCR assay, the TEs within the studied genomes demonstrated high variability in their abundance (Figure 1, Table S3). In P. spicata (St), Sabrina showed the predominant majority among the studied TEs followed by Angela- $A$ and WIS- $A$, whose abundance is $\sim 4$ times lower; Balduin is $\sim 6$ 
times lower. BAGY2 and BARE1C showed moderate abundance, Latidu, Geneva, Barbara and Veju has low abundance (Figure S2a). In Th. bessarabicum $\left(\mathrm{J}^{\mathrm{b}}\right)$, the highest abundance was demonstrated similarly by Angela- $A$ and WIS- $A$ followed by Sabrina and BAGY 2 which content is $\sim 2$ and $\sim 7$ times lower, respectively. Barbara, Balduin, and BARE1C showed moderate abundance; Geneva, Veju, and Latidu have low abundance (Figure S2b). In D. villosum (V), the highest abundance was shown by Sabrina, while Angela- $A$ and BAGY 2 content was 2 and 5 times lower, respectively. WIS- $A$ has moderate copy number, Veju, Barbara, Latidu, BARE1C and Balduin have low abundance (Figure S2c). In Th. intermedium average subgenome, Sabrina is the most abundant element; Angela- $A, B A G Y 2$ and WIS- $A$ content is $\sim 4$ times lower. Barbara, BARE1C and Balduin have moderate content; Veju, Latidu and Geneva abundance is low (Figure S2d).
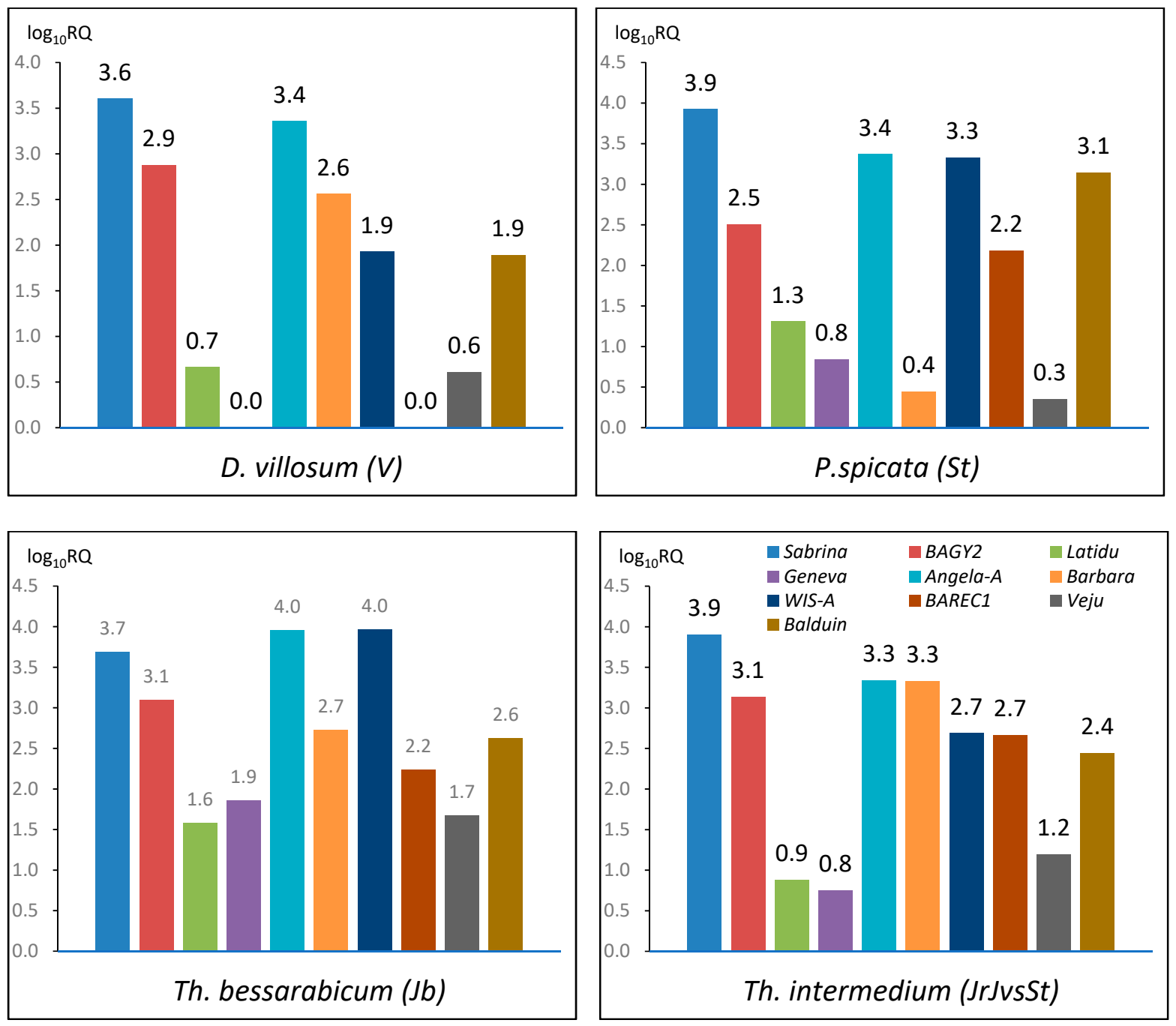

Figure 1. The decimal logarithm of relative quantity of TEs per one genome in P. spicata (St), Th. bessarabicum $\left(\mathrm{J}^{\mathrm{b}}\right)$, D. villosum $(\mathrm{V})$, Th. intermedium $\left(\mathrm{J}^{\mathrm{r}} \mathrm{J}^{\mathrm{vs}} \mathrm{St}\right.$, the plot is for one average subgenome).

\subsection{TE Copy Number Variation between Genomes}

We compared the abundance of TEs (NRQ) between studied species (Table S4) and, in addition, compared it to TE content in Aegilops and Triticum species measured by Yaakov et al. 2013 [28]. To perform such comparison, Ae. tauschii was included in the experiment as the calibrator, as it was used in Yaakov et al. 2013 [28]. It also should be noted that we study the abundance of TEs using primers developed for wheat sequences. Therefore, we investigated TEs that more likely have derived from the common ancestor of the studied species and Triticum/Aegilops diploids. For the comparison 
with genomes of the diploid species, the results of the TE's abundance in hexaploid Th. intermedium $\left(\mathrm{J}^{\mathrm{r}} \mathrm{J}^{\mathrm{vs}} \mathrm{St}\right)$ are described for one average diploid subgenome.

\subsubsection{Sabrina}

The content of Ty-3 Gypsy LTR retrotransposon Sabrina in St, $\mathrm{J}^{\mathrm{b}}$ and V genomes is close between each other (Figure S3). Moreover, it was comparable to the candidate donors of A, B and D genomes. The abundance in Th. bessarabicum $\left(\mathrm{J}^{\mathrm{b}}\right)$ and D. villosum $(\mathrm{V})(0.7$ and 0.5$)$ is close to Ae. speltoides (S) (0.3-1.3), in P. spicata (St) (1.1) is close to Ae. searsii (S $\mathrm{S}^{\mathrm{s}}$ (1.0-1.6), Ae. tauschii (D) (1.0) and T. urartu (A $\left.{ }^{\mathrm{u}}\right)$ (1.5). In one average subgenome of Th. intermedium $\left(\mathrm{J}^{\mathrm{r}} \mathrm{J}^{\mathrm{vs}} \mathrm{St}\right)$ Sabrina content is similar to the studied diploid species.

\subsection{2. $B A G Y 2$}

The content of Gypsy LTR retrotransposon BAGY2 was also similar between genomes in the studied diploids (Figure S4). In P. spicata (St) (0.7) the BAGY2 content was most close to its content observed in Ae. longissima (0.7) and was slightly lower than its content in Ae. speltoides (S) (0.8-1.4). The BAGY2 abundance determined in our work in D. villosum (V) (1.6) and normalized to Ae. tauschii was in the range of variation of the abundance in Ae. searsii $\left(\mathrm{S}^{\mathrm{S}}\right)$ (1.5-3.9). Among diploid species studied in our work the highest abundance was revealed in Th. bessarabicum $\left(\mathrm{J}^{\mathrm{b}}\right)(2.4)$. In one average subgenome of Th. intermedium ( $\mathrm{J}^{\mathrm{r}} \mathrm{J}^{\mathrm{vs}} \mathrm{St}$ ) BAGY2 content was close to that in $\mathrm{St}, \mathrm{J}^{\mathrm{b}}$ and $\mathrm{V}$ genomes.

\subsubsection{Latidu}

The abundance of Gypsy LTR retrotransposon Latidu in St and $\mathrm{J}^{\mathrm{b}}$ genomes was rather close; in V genome of $D$. villosum its abundance was three orders of magnitude lower than in St and $\mathrm{J}^{\mathrm{b}}$ genomes (Figure 2). Additionally, the observed copy number in $\mathrm{St}$ and $\mathrm{J}^{\mathrm{b}}$ was similar to that in the potential donors of B and D genomes of wheat: the abundance in P. spicata (St) (1.1) and Th. bessarabicum $\left(\mathrm{J}^{\mathrm{b}}\right)$ (2.2) was in the range of Ae. speltoides (S) (0.6-3.0) and Ae. tauschii (D) (1.0). In one average subgenome of Th. intermedium ( $\mathrm{J}^{\mathrm{r}} \mathrm{J}^{\mathrm{vs}} \mathrm{St}$ ) Latidu content was closer to that in $\mathrm{St}$ and $\mathrm{J}^{\mathrm{b}}$ genomes.

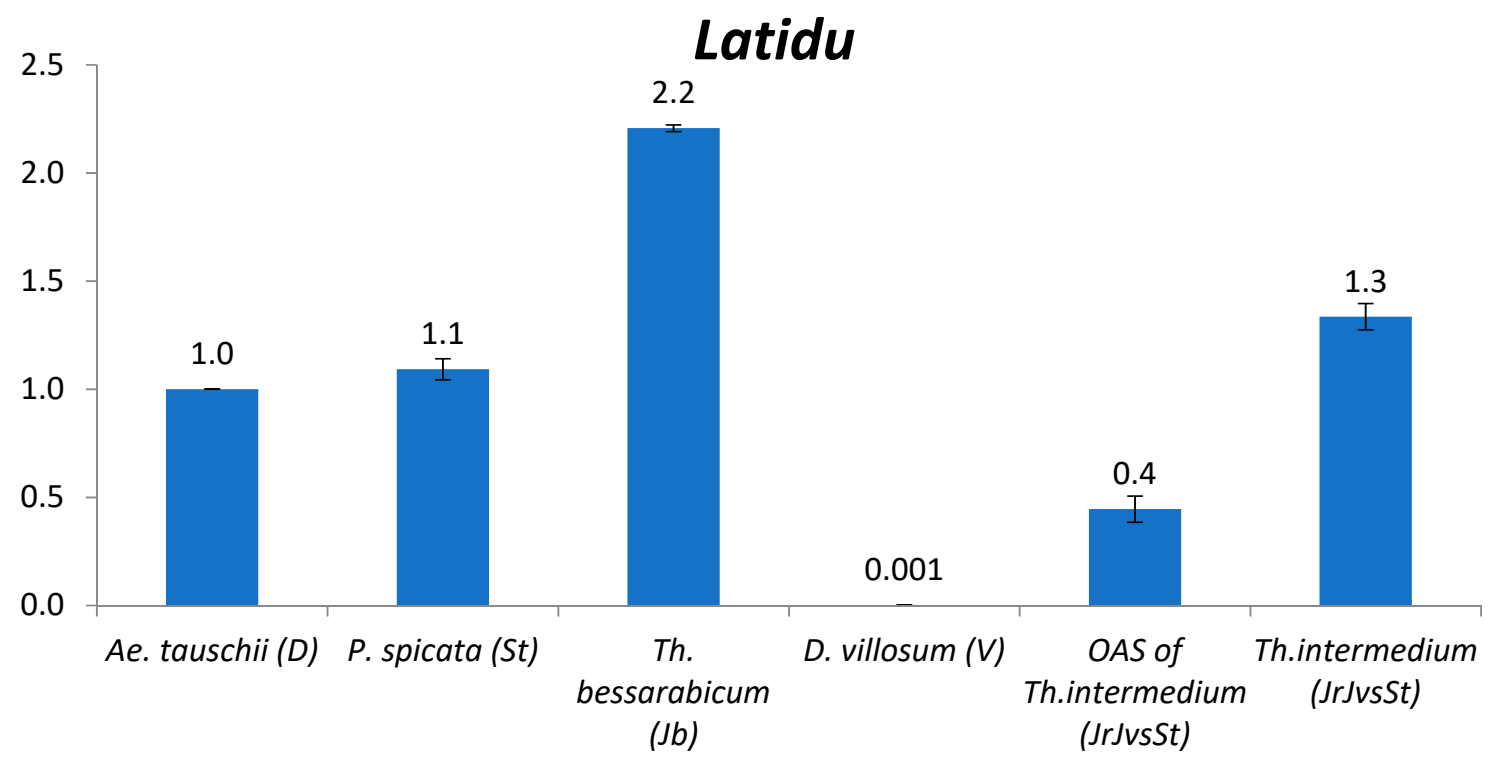

Figure 2. Relative quantification (compared to Ae. tauschii, which is taken as 1, see text) of Gypsy LTR retrotransposon Latidu in the following species: Ae. tauschii, P. spicata, Th. bessarabicum, D. villosum, one average subgenome (OAS) of Th. intermedium, and Th. intermedium. The numbers above chart bars are decimal logarithm of relative quantity of TEs; error bars show standard deviation. 


\subsubsection{Geneva}

The content of Gypsy LTR retrotransposon Geneva is close between St and V genomes and 10 times lower than in $\mathrm{J}^{\mathrm{b}}$ (Figure 3). The Geneva copy number in $\mathrm{St}$ and $\mathrm{V}$ is similar to that in candidate donors of B, D and A genomes of wheat: P. spicata (St) and D. villosum (V) (0.6 and 0.4) are close to Ae. searsii $\left(\mathrm{S}^{\mathrm{S}}\right)$ and T. urartu $\left(\mathrm{A}^{\mathrm{u}}\right)(0.3-0.7)$. Geneva content in Th. bessarabicum $\left(\mathrm{J}^{\mathrm{b}}\right)(6.1)$ is approximately one order magnitude higher than in A, B, D, St and V. In one average subgenome of Th. intermedium $\left(\mathrm{J}^{\mathrm{r}} \mathrm{J}^{\mathrm{vs}} \mathrm{St}\right.$ ) Geneva content was close to $\mathrm{St}$ and $\mathrm{V}$ subgenomes.

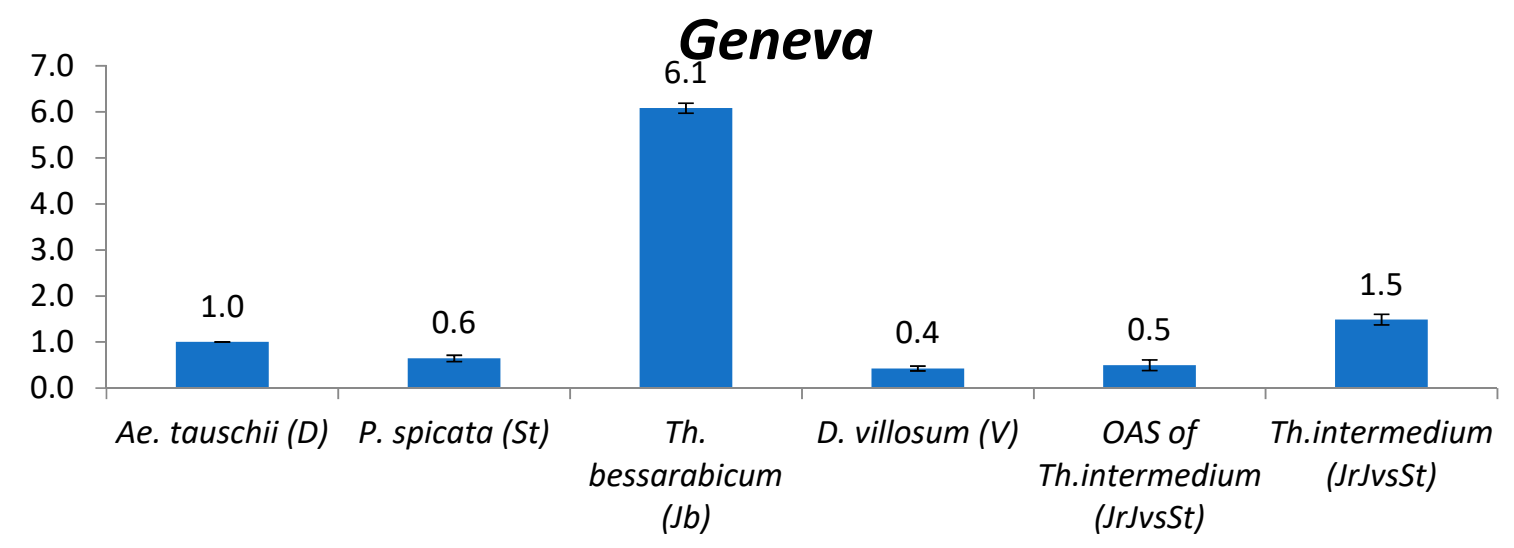

Figure 3. Relative quantification (compared to Ae. tauschii, set as 1, see text) of Gypsy LTR retrotransposon Geneva in the following species: Ae. tauschii, P. spicata, Th. bessarabicum, D. villosum, one average subgenome (OAS) of Th. intermedium, and Th. intermedium. The numbers above chart bars are decimal logarithm of relative quantity of TEs; error bars show standard deviation.

\subsubsection{Angela- $A$}

The abundance of Copia LTR retrotransposon Angela- $A$ abundance in the studied diploid and polyploid species was relatively close between each other (Figure S5). Only Th. bessarabicum $\left(\mathrm{J}^{\mathrm{b}}\right.$ ) (3.0) slightly prevailed in copy number both diploids and polyploids as calculated per one genome. Th. intermedium ( $\mathrm{J}^{\mathrm{r}} \mathrm{v}^{\mathrm{vs}} \mathrm{St}$ ) in its average genome has Angela- $A$ abundance close to $\mathrm{St}, \mathrm{J}^{\mathrm{b}}$ and $\mathrm{V}$ genomes. The abundance of Angela- $A$ in the studied genomes (1.1-3.0) was in the range (0.7-9.3) observed in diploids and polyploids studied in Yaakov et al. (2013).

\subsubsection{Barbara}

Barbara demonstrated dramatic differences between the studied genomes: its content in P. spicata (St) and D. villosum $(\mathrm{V})$ is two orders of magnitude lower than in $\mathrm{J}^{\mathrm{b}}$ genome (Figure 4). The abundance of Copia LTR retrotransposon Barbara in St, $\mathrm{J}^{\mathrm{b}}$ and V genomes (0.0006-0.3) is much lower than in Aegilops and Triticum diploids. One average subgenome of Th. intermedium $\left(\mathrm{J}^{\mathrm{r}} \mathrm{J}^{\mathrm{vs}} \mathrm{St}\right.$ ) has Barbara content two orders of magnitude higher than $\mathrm{St}$ and $\mathrm{V}$ and close to $\mathrm{J}^{\mathrm{b}}$ genome. 


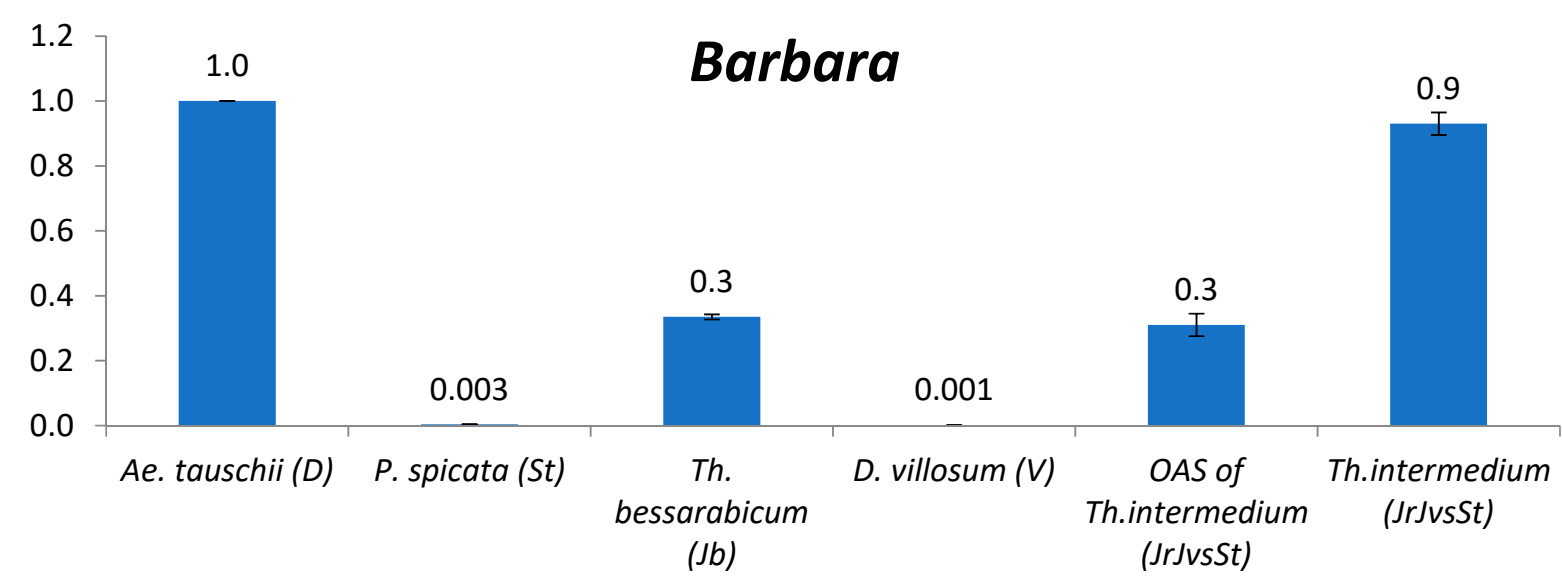

Figure 4. Relative quantification (compared to Ae. tauschii, set as 1, see text) of Copia LTR retrotransposon Barbara in the following species: Ae. tauschii, P. spicata, Th. bessarabicum, D. villosum, one average subgenome of Th. intermedium, and Th. intermedium. The numbers above chart bars are decimal logarithm of relative quantity of TEs; error bars show standard deviation.

\subsubsection{WIS-A}

We observed a similarity in the abundance of Copia LTR retrotransposon WIS- $A$ between St (0.17) and $\mathrm{J}^{\mathrm{b}}(0.7)$ genomes; $\mathrm{V}$ genome (0.03) showed the least abundance (Figure S6). P. spicata (St) (0.17) and D. villosum (V) (0.03) have lower WIS-A content than Aegilops and Triticum diploids (0.5-4.6); Th. bessarabicum $\left(\mathrm{J}^{\mathrm{b}}\right)(0.7)$ is in the range of its copy number variation in Ae. speltoides (S) (0.5-4.6). In one average subgenome of Th. intermedium $\left(\mathrm{J}^{\mathrm{r}} \mathrm{J}^{\mathrm{vs}} \mathrm{St}\right)$ WIS-A abundance $(0.16)$ is in the range of diploid species P. spicata and Th. bessarabicum.

\subsubsection{BARE1C}

The content of Copia LTR retrotransposon in P. spicata (St), Th. bessarabicum $\left(\mathrm{J}^{\mathrm{b}}\right)$ and D. villosum $(\mathrm{V})$ $(0.2-0.3)$ was very much close between diploid species (Figure S7). The revealed range between $\mathrm{St}, \mathrm{V}$ and $\mathrm{J}^{\mathrm{b}}$ was lower than in Aegilops and Triticum diploids (1.0-10.8). The BARE1C content in one average subgenome of $T h$. intermedium $\left(\mathrm{J}^{\mathrm{r}} \mathrm{J}^{\mathrm{vs}} \mathrm{St}\right.$ ) is $\sim 4$ times its content in the studied diploids.

\subsubsection{Veju}

The abundance of Copia-like LTR retrotransposon Veju is close between St and V genomes; in $\mathrm{J}^{\mathrm{b}}$ genome it is slightly higher (Figure S8). P. spicata (St) (0.1) and D. villosum (V) (0.2) have lower Veju abundance than Aegilops and Triticum diploids (1.0-10.4), Th. bessarabicum ( $\left.\mathrm{J}^{\mathrm{b}}\right)(1.3)$ is close to Ae. tauschii (D) (1.0). In one average subgenome of Th. intermedium the Veju content (0.4) is close to St and $\mathrm{V}$ genomes.

\subsubsection{Balduin}

The only revealed in our study DNA transposon is CACTA TIR transposon Baldiun. It demonstrated similarity between $\mathrm{J}^{\mathrm{b}}(0.3)$ and $\mathrm{V}(0.1)$ genomes, the latter differed considerably from St genome (1.5) (Figure 5). P. spicata (St) (1.5) showed the highest abundance among studied diploids compared to T. urartu $\left(\mathrm{A}^{\mathrm{u}}\right)$; Th. bessarabicum $\left(\mathrm{J}^{\mathrm{b}}\right)(0.3)$ Veju content is close to Ae. searsii $\left(\mathrm{S}^{\mathrm{s}}\right)$; D. villosum $(\mathrm{V})$ has the least quantity. In one average subgenome of Th. intermedium $\left(\mathrm{J}^{\mathrm{r}} \mathrm{J}^{\mathrm{vs}} \mathrm{St}\right)$, Baldiun content is one order of magnitude lower than is in P. spicata (St). 


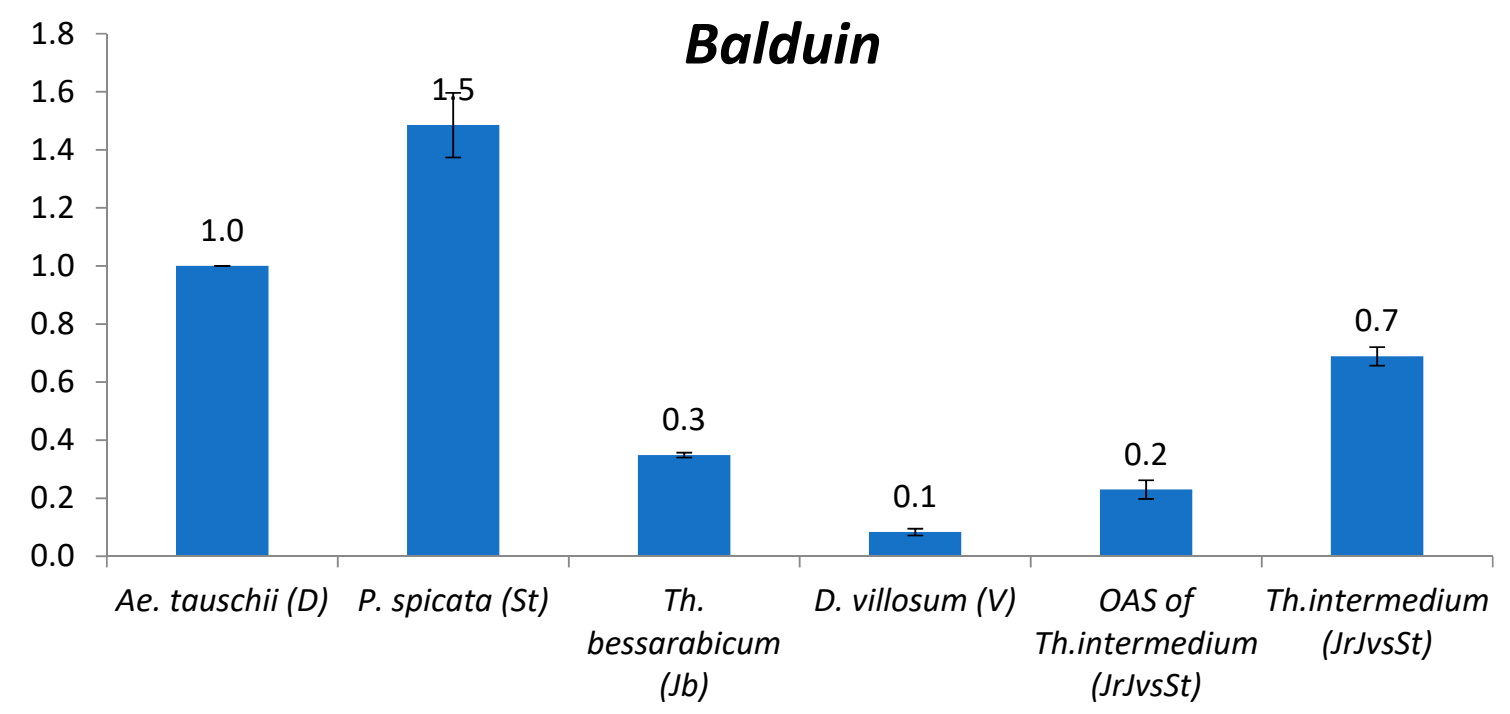

Figure 5. Relative quantification (compared to Ae. tauschii, set as 1, see text) of CACTA TIR transposon Balduin in the following species: Ae. tauschii, P. spicata, Th. bessarabicum, D. villosum, one average subgenome of Th. intermedium, and Th. intermedium. The numbers above chart bars are decimal logarithm of relative quantity of TEs; error bars show standard deviation.

\section{Discussion}

In our qPCR experiments, we used the primers for TEs that were verified and proved that that they can be used to adequately assess TE abundance [28]. Therefore, if in our experiments with a given species, we observed positive amplification from a pair of the primers developed for a given Triticum/Aegilops TE, we may conclude that this particular TE had been present in the genome of the common ancestor of Triticum/Aegilops and the studied species. The difference in abundance between Triticum/Aegilops and our wheat related species evolved from the common ancestor could have occurred because of TE proliferation/elimination, methylation, polyploidization and other evolutionary factors. We here, for the first time, studied the abundance of nine LTR retrotransposons of Gypsy (Latidu, Sabrina, BAGY2, Geneva) and Copia (Angela-A, Barbara, WIS-A, BARE1C, and Copia-like Veju) superfamilies and one TIR transposon (Balduin) in P. spicata (St), Th. bessarabicum $\left(\mathrm{J}^{\mathrm{b}}\right)$, D. villosum $(\mathrm{V})$, Th. intermedium $\left(\mathrm{J}^{\mathrm{r}} \mathrm{J}^{\mathrm{vs}} \mathrm{St}\right)$. Because of using Ae. tauschii as a calibrator we could compare the observed TE content in the studied species with published data for Ae. searsii $\left(\mathrm{S}^{\mathrm{s}}\right)$, Ae. speltoides $(\mathrm{S})$, Ae. sharonensis $\left(\mathrm{S}^{\mathrm{sh}}\right)$, Ae. longissima $\left(\mathrm{S}^{\mathrm{l}}\right)$, T. urartu $\left(\mathrm{A}^{\mathrm{u}}\right)$, Ae. tauschii (D), T. turgidum ssp. dicoccoides (BA), T. turgidum ssp. durum (BA), and T. aestivum (BAD) [28].

\subsection{The Comparison of TE Content within Genomes}

In our experiments, the analysis of the relative quantities of four Gypsy retrotransposons families (Sabrina, Latidu, BAGY2, Geneva) demonstrated that together they comprise the majority of all studied TEs (and LTR retrotransposons, in particular), in all studied species with the exception for Th. bessarabicum. Of the TE components, Ty3/Gypsy, Ty3/Copia and CACTA are the most abundant in the published genomes of wheat, barley, T. urartu, and Ae. tauschii, Agropyron cristatum and Secale cereale [27,50,56,82]. In all studied species, Sabrina and BAGY2 are highly abundant and dominates over other Gypsy LTR retroelements, while BAGY2 is being less abundant than Sabrina. Moreover, non-autonomous Gypsy element Sabrina is the most abundant element among all studied elements in P. spicata and D. villosum andin polyploid Th. intermedium. Also, Sabrina is the second abundant element in many Triticeae species (T. urartu, T. boeoticum, T. monococcum, Ae. tauschii, T. aestivum, H. spontaneum, H. vulgare, S. cereale) $[6,27,82]$. Gypsy element BAGY2 was found to be the third in abundance among the most abundant TEs in Hordeum, but has very low content in Triticum and Aegilops genomes [27,82]. In Th. bessarabicum and D. villosum the BAGY2 content was comparable to the most abundant element 
and were fourth and third in the most abundant elements, respectively. In polyploid Th. intermedium, $B A G Y 2$ was the fourth most abundant element.

In our experiments, in all studied species Copia elements Angela- $A$ and WIS- $A$ showed very high and very close abundance, with exception for $D$. villosum (V), in which WIS- $A$ content was $\sim 6$ times lower than Angela-A. In Th. bessarabicum $\left(\mathrm{J}^{\mathrm{b}}\right)$ Angela- $A$ and WIS- $A$ comprised the predominant majority; in P. spicata (St) and Th. bessarabicum $\left(\mathrm{J}^{\mathrm{b}}\right)$ Angela- $A$ was the second abundant element. The BARE1 clade in barley and Angela-A/Wis clade in wheat comprise approximately $10 \%$ of their genome and represent high-copy elements in Triticeae [6,83-86]. It should be noted that WIS and Angela are the wheat homologues of BARE1 found in barley and in some studies, they are treated as the same family BARE1 [6,27] or Angela-A [87]. In poylpoid Th. intermedium, Angela- $A$ and WIS-A were found to be in the most abundant elements. BARE1C demonstrated rather moderate abundance in all studied species that may be explained by its specificity for Hordeum species. This clade is considered to have existed before the divergence of monocots and dicots, $150 \mathrm{My}$ ago [86]. Perhaps, BARE1C had been substituted by or transformed into its analogues Angela- $A$ and WIS- $A$ in the common ancestor of A, B, D, St, $\mathrm{J}^{\mathrm{b}}$, and $\mathrm{V}$ genomes. Barbara showed from low to moderate abundance in the studied species; Copia-like element Veju demonstrated rather low abundance in all studied species.

\subsection{The Comparison of TE Content between Genomes}

The following patterns were found between $\mathrm{St}, \mathrm{J}^{\mathrm{b}}, \mathrm{V}, \mathrm{A}^{\mathrm{u}}, \mathrm{S}$, and $\mathrm{B}$ genome diploids when the data on the TE abundance was combined with the phylogenetic tree based on the GBSSI gene sequences [88] (Figures S9-S11). Sabrina, BAGY2, and Angela-A demonstrated relative similarity between Thinopyrum and Triticum-related species that may indicate that the elements were inserted in their common ancestor and that the content of these elements was not changed dramatically since that time. Latidu, Geneva, Barbara, and WIS-A demonstrated dramatic differences between both Thinopyrum and Triticum-related species. This may be associated with their low content in their common ancestor and further multiple reinsertion and proliferation in particular genomes after their divergence. In general, the TE content in Th. bessarabicum was the most similar to Triticum/Aegilops diploids, especially, to Ae. tauschii that may be associated with their speciation from the common ancestor.

The abundance of Gypsy LTR retrotransposons Sabrina and BAGY2 in the studied diploids, hexaploid Th. intermedium and Triticum/Aegilops diploids were quite close (Figure S9). It may be the evidence of that these TE's increased their abundance in the common ancestor and then did not change it significantly after the divergence of the considered species. Sabrina is probably an ancient element that inserted into common ancestor of Triticeae at least 9.65 million years ago (Mya) and then insertion events repeated multiple times $[89,90]$. Sabrina-like LTR pDbH12 was used to develop PCR and FISH markers to differentiate genomes $\mathrm{V}\left(\right.$ D. villosum), $\mathrm{V}^{\mathrm{b}}$ (D.breviaristatum), and $\mathrm{J}^{\mathrm{vs}}$ (Th. intermedium) from other Triticeae genomes [60,91]. Among other members of Gypsy superfamily Sabrina demonstrated the lowest evolutionary dynamics [28]. We can suggest that all subsequent Sabrina proliferations that occurred in the genomes of Triticeae species were not so dramatic as compared to the first massive insertion event(s) in the common Triticeae ancestor.

Copia LTR retrotransposons Angela- $A$, WIS- $A$, and BARE1C are clustered as one ancient clade in the published studies; they have reinserted in wheat and barley genomes for multiple times for more than 3 million years and show different copy number variation among Triticeae species $[27,86]$. Angela- $A$ showed similar abundance among the studied diploids, hexaploid Th. intermedium as well as in Triticum/Aegilops diploids [28] that may indicate its evolutionary stability.

BARE1C was shown to be much more abundant in Secale and Hordeum rather than in Triticum/Aegilops species [27]. In our studies, diploid P. spicata, Th. bessarabicum, and D. villosum demonstrated the BARE1C abundance even lower than in Triticum/Aegilops species (Figure S10). In polyploid Th. intermedium, BARE1C content was higher than in its relative diploids. Therefore, we may suppose that once inserted in the common ancestor of Triticeae it became later more abundant in Hordeum and Secale (H-R) and less abundant in Triticum/Aegilops and Thinopyrum-related species. 
However, it kept its evolutionary activity in Triticum/Aegilops species [28] and, perhaps, might have played a significant role at polyploidization in Thinopyrum intermedium. $\mathrm{J}^{\mathrm{r}}$ subgenome of Th. intermedium and R genome of Secale share genomic sequences [63,92] that also might be associated with higher abundance of BARE1C in Th. intermedium compared to its related diploid species.

WIS- $A$ is supposed to have inserted for the first time in Triticeae ancestor at least 4.5 Mya and characterized by relatively low activity in wheat $[28,89]$. In our experiments, its abundance was lower than in Triticum/Aegilops species that may indicate its evolutionary elimination in this V-St branch of Triticeae speciation. Interestingly, Monte et al. (1995) clustered Th. bessarabicum with Triticum species based on WIS 2-1A sequences [93]; in our experiments, Th. bessarabicum demonstrated WIS-A abundance the most similar to Aegilops tauschii among other studied species (Figure S10). In the phylogenic studies, the J genome of Thinopyrum was shown to be closer to D genome of Ae. tauschii than St $[88,94,95]$. The similarity in TE content may be the possible reason for such closeness and the drive force for the recombination between these genomes [23]. That may explain why the majority of chromosomal rearrangements in wide hybrids occurs between $\mathrm{J}^{\mathrm{r}}$ и ${ }^{\mathrm{vs}}$ genomes of Th. intermedium and D genome of wheat [96].

The abundance of Copia LTR retrotransposon Barbara and Veju in St and V genomes is lower than in Aegilops and Triticum diploids. Barbara and Veju are recent elements that character for Triticum/Aegilops species and are affected in early generations in experimentally derived hybrids $[28,40,86,97]$. In the $\mathrm{J}^{\mathrm{b}}$ genome of Th. bessarabicum, Veju and Barbara abundance was the closest to D genome of Ae. tauschii among studied species that may explain the $\mathrm{J}^{\mathrm{b}}$ and $\mathrm{D}$ genomes proximity and might be associated with their recent divergence from the common $\mathrm{J}^{\mathrm{b}}$-D ancestor (Figure S10). The suggestions inferred from our results coincides with the phylogenetic tree based on the GBSSI sequences [88].

Sharp differences in Latidu and Barbara abundance (several orders of magnitude) and more slight differences in Geneva, Veju, and Balduin between St, $\mathrm{J}^{\mathrm{b}}$, and V genome diploids (Figures S9-S11) could have favored a necessary level of difference between homeologous chromosomes of closely related subgenomes in newly formed Thinopyrum allopolyploids for relatively stable meiosis. In this case, the differences in certain TEs between putative contributors of subgenomes in Thinopyrum polyploids could have been a condition for efficient coexistence of them in one allopolyploid genome and functioning in one organism $[23,73,98]$. The comparison between the TE abundance in the $\mathrm{St}, \mathrm{J}^{\mathrm{b}}$, and $\mathrm{V}$ genome diploids and allopolyploid Th. intermedium revealed the following trends (Figure S12). Latidu, Geneva, Angela-A, and Balduin in their sum of contents in St, $\mathrm{J}^{\mathrm{b}}$, and $\mathrm{V}$ exceeded their content in the whole genome of Th. intermedium. This may be explained by either the increase in their content in Th. bessarabicum (in case of Latidu, Geneva, Angela-A) and P. spicata (in case of Balduin) after the speciation of Th. intermedium or by their repression in Th. intermedium genome after allopolyploidization (Figure S12). In contrast, Sabrina, BAGY2, Barbara, and BARE1C in their sum of $\mathrm{St}, \mathrm{J}^{\mathrm{b}}$, and $\mathrm{V}$ was lower compared to the abundance observed in the whole genome of Th. intermedium that may be explained by their possible proliferation in intermedium wheatgrass after it evolved. Such changes in TE copy number are referred to as 'genetic shock' that is associated with the formation of new alleles, illegitimate recombination and chromosome rearrangements. However, the selection against such instability is relaxed due to the increase in gene copy number because of combining homeologs in one genome. As a result, polyploids with new benefit allelic variants and gene blocks may evolve that are more adapted to adverse environmental conditions [23]. This may be one of the reasons why polyploid Th. intermedium $(2 n=42)$ and Th. ponticum $(2 n=70)$ are widely used as sources of valuable genes for wheat improvement via wide hybridization [99].

In one average subgenome of Th. intermedium ( $\mathrm{J}^{\mathrm{r}} \mathrm{J}^{\mathrm{vs}} \mathrm{St}$ ) Latidu content was comparable to that in St and $\mathrm{J}^{\mathrm{b}}$ genomes, whereas in $\mathrm{V}$ genome of $D$. villosum it was three orders of magnitude lower than in $\mathrm{St}$ and J. Barbara also showed close abundance between one average subgenome of Th. intermedium and $\mathrm{J}^{\mathrm{b}}$ genome of Th. bessarabicum, while its content in St and V genomes was three orders of magnitude lower than in $\mathrm{J}^{\mathrm{b}}$ genome. Apparently, the highest contribution to the Latidu abundance in Th. intermedium genome was made by the progenitors of P. spicata and Th. bessarabicum, while that of Barbara was made by the Th. bessarabicum progenitor. 
Geneva content was comparable between St and V genomes and one average subgenome of Th. intermedium $\left(\mathrm{J}^{\mathrm{r}} \mathrm{J}^{\mathrm{vs}} \mathrm{St}\right)$, whereas in $\mathrm{J}^{\mathrm{b}}$ genome it was in several orders of magnitude higher; similar situation albeit with more slight differences is observed in Angela- $A$. On one hand, we may assume that these TEs proliferated in the Th. bessarabicum progenitor after the speciation of Th. intermedium. Alternatively, their content in $\mathrm{J}^{\mathrm{b}}$ subgenome donor was much higher than in $\mathrm{St}$ and $\mathrm{V}$ progenitors as today, but in a newly formed Th. intermedium genome it was suppressed and eventually eliminated (Figure S12).

\section{Conclusions}

In conclusion, in this research, we have performed an analysis of the relative quantity of $9 \mathrm{TE}$ families representing retrotransposons and $1 \mathrm{TE}$ family of DNA transposon in hexapoloid Th. intermedium $\left(\mathrm{J}^{\mathrm{r}} \mathrm{J}^{\mathrm{vs}} \mathrm{St}\right.$ ) and its hypothetical subgenome contributors, three related diploids P. spicata $(\mathrm{St})$, Th. bessarabicum $\left(\mathrm{J}^{\mathrm{b}}\right)$, and D. villosum $(\mathrm{V})$ and compared its abundance with Triticum/Aegilops species. We discovered, the Sabrina, BAGY2, and Angela-A demonstrated similar abundance in St, $\mathrm{J}^{\mathrm{b}}, \mathrm{V}$ and Triticum/Aegilops genomes that may indicate that its massive proliferation in their putative common ancestor. BARE1C showed close abundance between $\mathrm{St}, \mathrm{J}^{\mathrm{b}}, \mathrm{V}$ and lower abundance than in $\mathrm{B}, \mathrm{A}$ and $\mathrm{D}$ subgenome contributors that may be associated with their elimination in the $\mathrm{St}-\mathrm{Jb}-\mathrm{V}$ possible common ancestor. Latidu and Barbara showed sharp differences and Geneva, Veju, Balduin, and WIS- $A$ showed slighter differences between $\mathrm{St}, \mathrm{J}^{\mathrm{b}}$, and $\mathrm{V}$ that may indicate that their evolution more probably associated with $P$. spicata, Th. bessarabicum and D. villosum speciation rather than with their common ancestor. Based on the close abundance we may suggest that Latidu contribution in Th. intermedium genome was made by the progenitors of $P$. spicata and Th. bessarabicum, while that of Barbara was made by the Th. bessarabicum progenitor. Higher content BARE1C in Th. intermedium may be associated with $\mathrm{J}^{\mathrm{r}}$ relationship to $\mathrm{R}$ genome in Secale cereale, where this TE is abundant; WIS- $A$, Veju and Barbara content in Th. bessarabicum and Th. intermedium was close to Ae. tauschii that may be associated with the closeness of $\mathrm{J}^{\mathrm{b}}$, $\mathrm{J}^{\mathrm{r}}$ and $\mathrm{J}^{\mathrm{vs}}$ to $\mathrm{D}$ genome.

\section{Materials and Methods}

\subsection{Plant Material}

The plants were obtained from Germplasm Research International Network: P. spicata (PI 635993), Th. bessarabicum (PI 531711), D. villosum (W6 21717), Th. intermedium (PI 401200), and Ae. tauschii (Clae 3). DNA was extracted according to the protocol in [100] from the leaves of adult plants growing in the greenhouse.

\subsection{Quantitative PCR}

qPCR assay was performed according to Yaakov et al. (2013) [28]. The abundance of the studied TEs was estimated for target species, P. spicata, Th. bessarabicum, D. villosum, and Th. intermedium. To compare TE's abundance between the target species, we used Ae. tauschii as a calibrator, since this species demonstrated the positive amplification of all the studied TEs in [28].

Each independent experiment was repeated minimum three times. In each experiment the real-time qPCR amplification was run in triplicate reactions (technical replicates) on the LightCycler ${ }^{\circledR} 96$ instrument (Roche Diagnostics, Mannheim, Germany). Each PCR mix consisted of $2.5 \mu \mathrm{L}$ of reaction mix containing Eva Green ${ }^{\circledR}$ (Syntol LTD, Hamilton, New Zeland), serially diluted DNA template $(10,2,0.4$ and $0.08 \mathrm{ng}), 1.0 \mu \mathrm{L}$ of each forward and reverse primer $(10 \mathrm{pM} / \mu \mathrm{L})$. We quantified the following transposable elements: LTR retrotransposons of Ty3/Gypsy (Latidu, Sabrina, BAGY2, Geneva) and Ty1/Copia (Angela-A, Barbara, WIS-A, BARE1C, and Copia-like Veju) superfamilies; TIR transposon (Balduin); for qPCR we used the primers designed in Yaakov et al. (2013) (Table S5). We compared each reaction to amplification of the VRN1 gene (reference gene), as this gene is found in one copy in wheat 
genome and other studied genome as well [52]. As a result of qPCR, the value of the threshold cycle $(\mathrm{Cq})$ was registered for each reaction.

The efficiency of the PCR reactions (E) was determined by a standard curve through serial dilutions for the primer pairs for reference gene and target sequences for each species and calculated using the LightCycler ${ }^{\circledR} 96$ software and can be found in Table S1. The further PCRs for the calculations of TE abundance were done using primers with efficiency in the range of 1.8-2.1. If the primer efficiency values were out of this range than the data were excluded from the calculations.

For validation of the absence of additional PCR products except for the amplified from the template of TE's DNA, we performed melting curve protocol using LightCycler ${ }^{\circledR} 96$ instrument immediately after amplifications and ran the products of the PCR reaction on agarose gel. Only primers that produced a single melting curve peak with similar melting temperature of the amplicon and a single electrophoregram band were included in the following study. Examples of melting curves can be found in Figure S1. Melting temperatures of the amplicons can be found in Table S2.

\subsection{TE's Copy Number Calculation}

In each species, the relative quantity of each TE (RQ) compared to the reference gene in the genome of a diploid species or in one average subgenome of polyploid Th. intermedium was calculated using the LightCycler ${ }^{\circledR} 96$ software [101] and used for the comparisons between the TE's quantities inside a given species genome (or average subgenome). The normalized relative quantity (NRQ) and standard deviation was calculated using the following equation [28,102]:

$$
\mathrm{NRQ}=N \cdot\left(\frac{E_{\mathrm{Ref}}{ }^{\mathrm{C} \mathrm{q}_{\text {target }}}}{E_{\mathrm{Tar}}{ }^{C \mathrm{q}_{\text {target }}}}: \frac{E_{\text {Ref }}{ }^{C \mathrm{q}_{\text {calibrator }}}}{E_{\mathrm{Tar}}{ }^{C} \mathrm{q}_{\text {calibrator }}}\right),
$$

where " $E_{\mathrm{Tar}}$ " and " $E_{\mathrm{Ref}}$ " stand for the efficiency of the primers for the studied target transposable elements and the reference gene (VRN1), respectively; "Cqtarget" and Cq $\mathrm{q}_{\text {calibrator" }}$ " stand for qPCR threshold cycles for the target species (P. spicata, Th. bessarabicum, D. villosum, and Th. intermedium) and the calibrator (Ae. tauschii), respectively. A part of the equation in parenthesis results in the quantification of TE's abundance per one genome for a diploid or one average subgenome for a polyploid; for a calculation of the TE's abundance in a whole haploid genome, it is multiplied by $\mathrm{N}$, which is equivalent to the ploidy level: $\mathrm{N}=1$ for a diploid species, $P$. spicata, Th. bessarabicum, and D. villosum, and for one average diploid subgenome of hexpaloid Th. intermedium; $\mathrm{N}=3$ for the estimation of TE's abundance in the whole genome of hexpaloid Th. intermedium. For the comparisons between diploids and hexaploid Th. intermedium we calculated the NRQ value for an average subgenome of Th. intermedium $(\mathrm{N}=1)$, as the amplification in PCR occurs from all three subgenomes in hexaploid and it cannot be found using qPCR from which subgenome in particular. Thus, NRQ in Ae. tauschii is equal to 1. NRQ values were used for comparing the TE's quantities between the studied genomes. The mean NRQ value and standard deviations were calculated as described in [103].

Supplementary Materials: The following are available online at http://www.mdpi.com/2223-7747/9/1/15/s1, Figure S1: Examples of melting curves for the fragments amplified in qPCR using primers for Geneva, WIS-A, and VRN1 (as a reference gene) in P. spicata, Th. bessarabicum, D. villosum, and Ae. tauschii, Figure S2: Relative quantity of TEs per one genome in the following species: a) P. spicata $(\mathrm{St}), \mathrm{b})$ Th. bessarabicum $\left.\left(\mathrm{J}^{\mathrm{b}}\right), \mathrm{c}\right)$ D. villosum $(\mathrm{V}), \mathrm{d})$ Th. intermedium ( $\mathrm{J}^{\mathrm{J}} \mathrm{J}^{\mathrm{vs}} \mathrm{St}$ ), Figure S3: Normalized relative quantity (compared to Ae. tauschii, set as 1, see text) of Gypsy LTR retrotransposon Sabrina in the following species: Ae. tauschii, P. spicata, Th. bessarabicum, D. villosum, one average subgenome (OAS) of Th. intermedium, and Th. intermedium. The numbers above chart bars are decimal logarithm of relative quantity of TEs; error bars show standard deviation, Figure S4: Normalized relative quantity (compared to Ae. tauschii, set as 1, see text) of Gypsy LTR retrotransposon BAGY2 in the following species: Ae. tauschii, P. spicata, Th. bessarabicum, D. villosum, one average subgenome (OAS) of Th. intermedium, and Th. intermedium. The numbers above chart bars are decimal logarithm of relative quantity of TEs; error bars show standard deviation, Figure S5: Normalized relative quantity (compared to Ae. tauschii, set as 1, see text) of Copia LTR retrotransposon Angela-A in the following species: Ae. tauschii, P. spicata, Th. bessarabicum, $D$. villosum, one average subgenome of Th. intermedium, and Th. intermedium. The numbers above chart bars are decimal logarithm of relative quantity of TEs; error bars show standard deviation, Figure S6: Normalized 
relative quantity (compared to Ae. tauschii, set as 1, see text) of Copia LTR retrotransposon WIS-A in the following species: Ae. tauschii, P. spicata, Th. bessarabicum, D. villosum, one average subgenome of Th. intermedium, and Th. intermedium. The numbers above chart bars are decimal logarithm of relative quantity of TEs; error bars show standard deviation, Figure S7: Normalized relative quantity (compared to Ae. tauschii, set as 1, see text) of Copia LTR retrotransposon BARE1C in the following species: Ae. tauschii, P. spicata, Th. bessarabicum, D. villosum, one average subgenome of Th. intermedium, and Th. intermedium. The numbers above chart bars are decimal logarithm of relative quantity of TEs; error bars show standard deviation, Figure S8: Normalized relative quantity (compared to Ae. tauschii, set as 1, see text) of Copia-like LTR retrotransposon Veju in the following species: Ae. tauschii, P. spicata, Th. bessarabicum, D. villosum, one average subgenome of Th. intermedium, and Th. intermedium. The numbers above chart bars are decimal logarithm of relative quantity of TEs; error bars show standard deviation, Figure S9: Normalized relative quantity (NRQ, compared to Ae. tauschii (D), set as 1, see text) of Gypsy LTR retrotransposons in the following species: T. urartu $\left(\mathrm{A}^{\mathrm{u}}\right)$, Ae. speltoides (S), Ae. tauschii (D) (Yaakov et al., 2013); P. spicata (St), Th. bessarabicum $\left(\mathrm{J}^{\mathrm{b}}\right)$, D. villosum $(\mathrm{V})$. The area of the circle is equal to the NRQ of each transposable element, Figure S10: Normalized relative quantity (NRQ, compared to Ae. tauschii (D), set as 1, see text) of Copia LTR retrotransposons in the following species: T. urartu $\left(\mathrm{A}^{\mathrm{u}}\right)$, Ae. speltoides (S), Ae. tauschii (D) (Yaakov et al., 2013); P. spicata (St), Th. bessarabicum $\left(\mathrm{J}^{\mathrm{b}}\right)$, D. villosum $(\mathrm{V})$. The area of the circle is equal to the NRQ of each transposable element, Figure S11: Normalized relative quantity (NRQ, compared to Ae. tauschii (D), set as 1, see text) of DNA transposon Balduin in the following species: T. urartu (A $\left.{ }^{\mathrm{u}}\right)$, Ae. speltoides (S), Ae. tauschii (D) (Yaakov et al., 2013); P. spicata (St), Th. bessarabicum $\left(\mathrm{J}^{\mathrm{b}}\right)$, D. villosum (V). The area of the circle is equal to the NRQ of each transposable element, Figure S12: Normalized relative quantity (compared to Ae. tauschii (D), set as 1, see text) of the studied mobile elements in the following species: P. spicata (St), Th. bessarabicum $\left(\mathrm{J}^{\mathrm{b}}\right)$, D. villosum (V), Th. intermedium ( $\mathrm{J}^{\mathrm{r}} \mathrm{J}^{\mathrm{vs}} \mathrm{St}$, per whole allopolyploid genome), Table S1: The efficiency of the primers used in qPCR experiments with serial dilutions of DNA template (10, 2, 0.4 and 0.08 ng per $25 \mu \mathrm{L}$ of PCR mix) for each primer pair as calculated using LightCycler96 software; Table S2: Melting temperature of the fragments amplified in GPCR in P. spicata, Th. bessarabicum, D. villosum, Th. intermedium; Table S3: The relative quantity (RQ) of nine LTR retrotransposons and one TIR transposon in $P$. spicata, Th. bessarabicum, D. villosum, Th. intermedium (per one average subgenome), Th. ponticum. The RQ is calculated per one average genome of each species, Table S4: Normalized relative quantity (NRQ, compared to Ae. taushii, set as 1) of nine LTR retrotransposons and one TIR transposon in P. spicata, Th. bessarabicum, D. villosum, Th. intermedium. In Th. intermedium, NRQ is calculated per one average subgenome $(\times 1)$ and per total genome $(\times 3)$; Table S5: Primer sequences for the transposable elements and reference gene VRN1 (Yaakov et al., 2013; Kraitshtein et al., 2010).

Author Contributions: Conceptualization, M.G.D. and P.Y.K.; methodology, M.G.D.; investigation, M.G.D. and P.Y.K.; validation, M.G.D. and P.Y.K.; formal analysis, P.Y.K. and M.G.D.; writing-original draft preparation, P.Y.K.; writing-review and editing M.G.D. and G.I.K.; supervision, M.G.D. and G.I.K.; funding acquisition, M.G.D. All authors have read and agreed to the published version of the manuscript.

Funding: This research was funded by Russian Foundation for Basic Research, grant number N 17-04-01871a.

Conflicts of Interest: The authors declare no conflict of interest.

\section{References}

1. Arabidopsis Genome Initiative. Analysis of the genome sequence of the flowering plant Arabidopsis thaliana. Nature 2000, 408, 796-815. [CrossRef] [PubMed]

2. Meyers, B. Abundance, distribution, and transcriptional activity of repetitive elements in the maize genome. Genome Res. 2001, 11, 1660-1676. [CrossRef] [PubMed]

3. Li, W.; Zhang, P.; Fellers, J.; Friebe, B.; Gill, B. Sequence composition, organization, and evolution of the core Triticeae genome. Plant J. 2004, 40, 500-511. [CrossRef] [PubMed]

4. Paux, E.; Roger, D.; Badaeva, E.; Gay, G.; Bernard, M.; Sourdille, P.; Feuillet, C. Characterizing the composition and evolution of homoeologous genomes in hexaploid wheat through BAC-end sequencing on chromosome 3B. Plant J. 2006, 48, 463-474. [CrossRef]

5. Charles, M.; Belcram, H.; Just, J.; Huneau, C.; Viollet, A.; Couloux, A.; Segurens, B.; Carter, M.; Huteau, V.; Coriton, O.; et al. Dynamics and differential proliferation of transposable elements during the evolution of the B and A genomes of wheat. Genetics 2008, 180, 1071-1086. [CrossRef]

6. Wicker, T.; Taudien, S.; Houben, A.; Keller, B.; Graner, A.; Platzer, M.; Stein, N. A whole-genome snapshot of 454 sequences exposes the composition of the barley genome and provides evidence for parallel evolution of genome size in wheat and barley. Plant J. 2009, 59, 712-722. [CrossRef]

7. Mayer, K.; Martis, M.; Hedley, P.; Šimková, H.; Liu, H.; Morris, J.; Steuernagel, B.; Taudien, S.; Roessner, S.; Gundlach, H.; et al. Unlocking the barley genome by chromosomal and comparative genomics. Plant Cell 2011, 23, 1249-1263. [CrossRef] 
8. Kejnovsky, E.; Hawkins, J.; Feschotte, C. Plant transposable elements: Biology and evolution. In Plant Genome Diversity; Wendel, J., Greilhuber, J., Doležel, J., Leitch, I., Eds.; Springer: Wien, Austria, 2012; Volume 1, pp. 17-34.

9. Bennetzen, J. The contributions of retroelements to plant genome organization, function and evolution. Trends Microbiol. 1996, 4, 347-353. [CrossRef]

10. Feschotte, C.; Jiang, N.; Wessler, S. Plant transposable elements: Where genetics meets genomics. Nat. Rev. Genet. 2002, 3, 329-341. [CrossRef]

11. Neumann, P.; Koblížková, A.; Navrátilová, A.; Macas, J. Significant expansion of Vicia pannonica genome size mediated by amplification of a single type of giant retroelement. Genetics 2006, 173, 1047-1056. [CrossRef]

12. Vitte, C.; Bennetzen, J. Analysis of retrotransposon structural diversity uncovers properties and propensities in angiosperm genome evolution. Proc. Natl. Acad. Sci. USA 2006, 103, 17638-17643. [CrossRef] [PubMed]

13. Paterson, A.; Bowers, J.; Bruggmann, R.; Dubchak, I.; Grimwood, J.; Gundlach, H.; Haberer, G.; Hellsten, U.; Mitros, T.; Poliakov, A.; et al. The Sorghum bicolor genome and the diversification of grasses. Nature 2009, 457, 551-556. [CrossRef] [PubMed]

14. Schnable, P.; Ware, D.; Fulton, R.; Stein, J.; Wei, F.; Pasternak, S.; Liang, C.; Zhang, J.; Fulton, L.; Graves, T.; et al. The B73 maize genome: Complexity, diversity, and dynamics. Science 2009, 326, 1112-1115. [CrossRef] [PubMed]

15. International Brachypodium Initiative. Genome sequencing and analysis of the model grass Brachypodium distachyon. Nature 2010, 463, 763-768. [CrossRef]

16. Tenaillon, M.; Hollister, J.; Gaut, B. A triptych of the evolution of plant transposable elements. Trends Plant Sci. 2010, 15, 471-478. [CrossRef]

17. Mascher, M.; Gundlach, H.; Himmelbach, A.; Beier, S.; Twardziok, S.; Wicker, T.; Radchuk, V.; Dockter, C.; Hedley, P.; Russell, J.; et al. A chromosome conformation capture ordered sequence of the barley genome. Nature 2017, 544, 427-433. [CrossRef]

18. Feschotte, C.; Pritham, E. DNA transposons and the evolution of eukaryotic genomes. Annu. Rev. Genet. 2007, 41, 331-368. [CrossRef]

19. Yuan, Y.; Wessler, S. The catalytic domain of all eukaryotic cut-and-paste transposase superfamilies. Proc. Natl. Acad. Sci. USA 2011, 108, 7884-7889. [CrossRef]

20. Fujimoto, R.; Takuno, S.; Sasaki, T.; Nishio, T. The pattern of amplification and differentiation of Ty1/Copia and Ty3/Gypsy retrotransposons in Brassicaceae species. Genes Genet. Syst. 2008, 83, 13-22. [CrossRef]

21. Belyayev, A.; Kalendar, R.; Brodsky, L.; Nevo, E.; Schulman, A.; Raskina, O. Transposable elements in a marginal plant population: Temporal fluctuations provide new insights into genome evolution of wild diploid wheat. Mobile DNA 2010, 1, 6. [CrossRef]

22. Petit, M.; Guidat, C.; Daniel, J.; Denis, E.; Montoriol, E.; Bui, Q.; Lim, K.; Kovarik, A.; Leitch, A.; Grandbastien, M.; et al. Mobilization of retrotransposons in synthetic allotetraploid tobacco. New Phytol. 2010, 186, 135-147. [CrossRef] [PubMed]

23. Vicient, C.; Casacuberta, J. Impact of transposable elements on polyploid plant genomes. Ann. Bot. 2017, 120, 195-207. [CrossRef] [PubMed]

24. Kashkush, K.; Feldman, M.; Levy, A. Transcriptional activation of retrotransposons alters the expression of adjacent genes in wheat. Nat. Genet. 2002, 33, 102-106. [CrossRef] [PubMed]

25. Wicker, T.; Buchmann, J.; Keller, B. Patching gaps in plant genomes results in gene movement and erosion of colinearity. Genome Res. 2010, 20, 1229-1237. [CrossRef] [PubMed]

26. Lisch, D.; Bennetzen, J. Transposable element origins of epigenetic gene regulation. Curr. Opin. Plant Biol. 2011, 14, 156-161. [CrossRef]

27. Middleton, C.; Stein, N.; Keller, B.; Kilian, B.; Wicker, T. Comparative analysis of genome composition in Triticeae reveals strong variation in transposable element dynamics and nucleotide diversity. Plant J. 2012, 73, 347-356. [CrossRef]

28. Yaakov, B.; Meyer, K.; Ben-David, S.; Kashkush, K. Copy number variation of transposable elements in Triticum-Aegilops genus suggests evolutionary and revolutionary dynamics following allopolyploidization. Plant Cell Rep. 2013, 32, 1615-1624. [CrossRef]

29. Belyayev, A. Bursts of transposable elements as an evolutionary driving force. J. Evol. Biol. 2014, 27, 2573-2584. [CrossRef] 
30. Keidar, D.; Doron, C.; Kashkush, K. Genome-wide analysis of a recently active retrotransposon, Au SINE, in wheat: Content, distribution within subgenomes and chromosomes, and gene associations. Plant Cell Rep. 2017, 37, 193-208. [CrossRef]

31. Keidar-Friedman, D.; Bariah, I.; Kashkush, K. Genome-wide analyses of miniature inverted-repeat transposable elements reveals new insights into the evolution of the Triticum-Aegilops group. PLoS ONE 2018, 13, e0204972. [CrossRef]

32. McClintock, B. The significance of responses of the genome to challenge. Science 1984, 226, 792-801. [CrossRef] [PubMed]

33. Piegu, B.; Guyot, R.; Picault, N.; Roulin, A.; Saniyal, A.; Kim, H.; Collura, K.; Brar, D.; Jackson, S.; Wing, R.; et al. Doubling genome size without polyploidization: Dynamics of retrotransposition-driven genomic expansions in Oryza australiensis, a wild relative of rice. Genome Res. 2006, 16, 1262-1269. [CrossRef] [PubMed]

34. Hawkins, J.; Proulx, S.; Rapp, R.; Wendel, J. Rapid DNA loss as a counterbalance to genome expansion through retrotransposon proliferation in plants. Proc. Natl. Acad. Sci. USA 2009, 106, 17811-17816. [CrossRef] [PubMed]

35. Lysak, M.; Koch, M.; Beaulieu, J.; Meister, A.; Leitch, I. The dynamic ups and downs of genome size evolution in Brassicaceae. Mol. Biol. Evol. 2008, 26, 85-98. [CrossRef]

36. Mascagni, F.; Barghini, E.; Giordani, T.; Rieseberg, L.; Cavallini, A.; Natali, L. Repetitive DNA and plant domestication: Variation in copy number and proximity to genes of LTR-Retrotransposons among wild and cultivated sunflower (Helianthus annuus) Genotypes. Genome Biol. Evol. 2015, 7, 3368-3382. [CrossRef]

37. Tetreault, H.; Ungerer, M. Long terminal repeat retrotransposon content in eight diploid sunflower species inferred from next-generation sequence data. G3 (Bethesda) 2016, 6, 2299-2308. [CrossRef]

38. Domb, K.; Keidar, D.; Yaakov, B.; Khasdan, V.; Kashkush, K. Transposable elements generate population-specific insertional patterns and allelic variation in genes of wild emmer wheat (Triticum turgidum ssp. dicoccoides). BMC Plant Biol. 2017, 17. [CrossRef]

39. Shams, I.; Raskina, O. Intraspecific and intraorganismal copy number dynamics of retrotransposons and tandem repeat in Aegilops speltoides Tausch (Poaceae, Triticeae). Protoplasma 2018, 255, 1023-1038. [CrossRef]

40. Raskina, O. Transposable elements in the organization and diversification of the genome of Aegilops speltoides Tausch (Poaceae, Triticeae). Int. J. Genom. 2018, 2018, 1-9. [CrossRef]

41. Kawakami, T.; Strakosh, S.; Zhen, Y.; Ungerer, M. Different scales of Ty1/Copia-like retrotransposon proliferation in the genomes of three diploid hybrid sunflower species. Heredity 2010, 104, 341-350. [CrossRef]

42. Yaakov, B.; Kashkush, K. Mobilization of Stowaway-like MITEs in newly formed allohexaploid wheat species. Plant Mol. Biol. 2012, 80, 419-427. [CrossRef] [PubMed]

43. Ben-David, S.; Yaakov, B.; Kashkush, K. Genome-wide analysis of short interspersed nuclear elements SINES revealed high sequence conservation, gene association and retrotranspositional activity in wheat. Plant J. 2013, 76, 201-210. [CrossRef] [PubMed]

44. Casacuberta, J.; Jackson, S.; Panaud, O.; Purugganan, M.; Wendel, J. Evolution of plant phenotypes, from genomes to traits. G3 (Bethesda) 2016, 6, 775-778. [CrossRef] [PubMed]

45. Wendel, J.; Jackson, S.; Meyers, B.; Wing, R. Evolution of plant genome architecture. Genome Biol. $2016,17$. [CrossRef]

46. Pagnotta, M.; Mondini, L.; Porceddu, E. Quantification and organization of WIS2-1A and BARE-1 retrotransposons in different genomes of Triticum and Aegilops species. Mol. Genet. Genom. 2009, 282, 245-255. [CrossRef]

47. Sarilar, V.; Palacios, P.; Rousselet, A.; Ridel, C.; Falque, M.; Eber, F.; Chèvre, A.; Joets, J.; Brabant, P.; Alix, K. Allopolyploidy has a moderate impact on restructuring at three contrasting transposable element insertion sites in resynthesized Brassica napus allotetraploids. New Phytol. 2013, 198, 593-604. [CrossRef]

48. Senerchia, N.; Felber, F.; Parisod, C. Contrasting evolutionary trajectories of multiple retrotransposons following independent allopolyploidy in wild wheats. New Phytol. 2014, 202, 975-985. [CrossRef]

49. Parisod, C.; Senerchia, N. Responses Of Transposable Elements To Polyploidy. Plant Transposable Elements 2012, 147-168.

50. Zhang, J.; Liu, Y.; Xia, E.; Yao, Q.; Liu, X.; Gao, L. Autotetraploid rice methylome analysis reveals methylation variation of transposable elements and their effects on gene expression. Proc. Natl. Acad. Sci. USA 2015, 112, E7022-E7029. [CrossRef] 
51. Parisod, C.; Alix, K.; Just, J.; Petit, M.; Sarilar, V.; Mhiri, C.; Ainouche, M.; Chalhoub, B.; Grandbastien, M. Impact Of Transposable Elements On The Organization And Function Of Allopolyploid Genomes. New Phytol. 2009, 186, 37-45. [CrossRef]

52. Kraitshtein, Z.; Yaakov, B.; Khasdan, V.; Kashkush, K. Genetic and epigenetic dynamics of a retrotransposon after allopolyploidization of wheat. Genetics 2010, 186, 801-812. [CrossRef] [PubMed]

53. Yaakov, B.; Kashkush, K. Methylation, transcription, and rearrangements of transposable elements in synthetic allopolyploids. Int. J. Plant Genom. 2011, 569826, 1-7. [CrossRef] [PubMed]

54. Yaakov, B.; Kashkush, K. Massive alterations of the methylation patterns around DNA transposons in the first four generations of a newly formed wheat allohexaploid. Genome 2011, 54, 42-49. [CrossRef] [PubMed]

55. Choulet, F.; Wicker, T.; Rustenholz, C.; Paux, E.; Salse, J.; Leroy, P.; Schlub, S.; Le Paslier, M.; Magdelenat, G.; Gonthier, C.; et al. Megabase level sequencing reveals contrasted organization and evolution patterns of the wheat gene and transposable element spaces. Plant Cell 2010, 22, 1686-1701. [CrossRef] [PubMed]

56. Bauer, E.; Schmutzer, T.; Barilar, I.; Mascher, M.; Gundlach, H.; Martis, M.; Twardziok, S.; Hackauf, B.; Gordillo, A.; Wilde, P.; et al. Towards a whole-genome sequence for rye (Secale cereale). Plant J. 2017, 89, 853-869. [CrossRef] [PubMed]

57. Liu, Q.; Li, X.; Zhou, X.; Li, M.; Zhang, F.; Schwarzacher, T.; Heslop-Harrison, J. The Repetitive DNA Landscape In Avena (Poaceae): Chromosome And Genome Evolution Defined By Major Repeat Classes In Whole-Genome Sequence Reads. BMC Plant Biology 2019, 19. [CrossRef]

58. Chen, Q.; Conner, R.; Laroche, A.; Thomas, J. Genome analysis of Thinopyrum intermedium and Thinopyrum ponticum using genomic in situ hybridization. Genome 1998, 41, 580-586. [CrossRef]

59. Kishii, M.; Wang, R.; Tsujimoto, H. GISH analysis revealed new aspect of genomic constitution of Thinopyrum intermedium. Czech J. Genet. Plant Breed. 2012, 41, 92-95. [CrossRef]

60. Liu, C.; Yang, Z.; Jia, J.; Li, G.; Zhou, J.; Ren, Z. Genomic distribution of a long terminal repeat (LTR) Sabrina-like retrotransposon in Triticeae species. Cereal Res. Commun. 2009, 37, 363-372. [CrossRef]

61. Deng, C.; Bai, L.; Fu, S.; Yin, W.; Zhang, Y.; Chen, Y.; Wang, R.; Zhang, X.; Han, F.; Hu, Z. Microdissection and chromosome painting of the alien chromosome in an addition line of wheat-Thinopyrum intermedium. PLOS ONE 2013, 8, e72564. [CrossRef]

62. Mahelka, V.; Kopecký, D.; Baum, B. Contrasting patterns of evolution of 45S and 5S rDNA families uncover new aspects in the genome constitution of the agronomically important grass Thinopyrum intermedium (Triticeae). Mol. Biol. Evol. 2013, 30, 2065-2086. [CrossRef] [PubMed]

63. Wang, R.; Larson, S.; Jensen, K.; Bushman, B.; DeHaan, L.; Wang, S.; Yan, X. Genome evolution of intermediate wheatgrass as revealed by EST-SSR markers developed from its three progenitor diploid species. Genome 2015, 58, 63-70. [CrossRef] [PubMed]

64. Hu, L.; Li, G.; Zeng, Z.; Chang, Z.; Liu, C.; Zhou, J.; Yang, Z. Molecular cytogenetic identification of a new wheat-Thinopyrum substitution line with stripe rust resistance. Euphytica 2010, 177, 169-177. [CrossRef]

65. Bao, Y.; Wu, X.; Zhang, C.; Li, X.; He, F.; Qi, X.; Wang, H. Chromosomal constitutions and reactions to powdery mildew and stripe rust of four novel wheat-Thinopyrum intermedium partial amphiploids. J. Genet. Genom. 2014, 41, 663-666. [CrossRef]

66. Grewal, S.; Yang, C.; Edwards, S.; Scholefield, D.; Ashling, S.; Burridge, A.; King, I.; King, J. Characterization of Thinopyrum bessarabicum chromosomes through genome-wide introgressions into wheat. Theor. Appl. Genet. 2017, 131, 389-406. [CrossRef]

67. Lang, T.; La, S.; Li, B.; Yu, Z.; Chen, Q.; Li, J.; Yang, E.; Li, G.; Yang, Z. Precise identification of wheat-Thinopyrum intermedium translocation chromosomes carrying resistance to wheat stripe rust in line Z4 and its derived progenies. Genome 2018, 61, 177-185. [CrossRef]

68. Petersen, G.; Seberg, O. Phylogenetic evidence for excision of Stowaway miniature inverted-repeat transposable elements in Triticeae (Poaceae). Mol. Biol. Evol. 2000, 17, 1589-1596. [CrossRef]

69. Markova, D.; Mason-Gamer, R. Diversity, abundance, and evolutionary dynamics of Pong-like transposable elements in Triticeae. Mol. Phylogenet. Evol. 2015, 93, 318-330. [CrossRef]

70. Markova, D.; Mason-Gamer, R. The role of vertical and horizontal transfer in the evolutionary dynamics of PIF-like transposable elements in Triticeae. PLOS ONE 2015, 10, e0137648. [CrossRef]

71. El Baidouri, M.; Panaud, O. Comparative genomic paleontology across plant kingdom reveals the dynamics of TE-driven genome evolution. Genome Biol. Evol. 2013, 5, 954-965. [CrossRef] 
72. Kalendar, R.; Amenov, A.; Daniyarov, A. Use of retrotransposon-derived genetic markers to analyse genomic variability in plants. Funct. Plant Biol. 2019, 46, 15. [CrossRef] [PubMed]

73. Divashuk, M.; Khuat, T.; Kroupin, P.; Kirov, I.; Romanov, D.; Kiseleva, A.; Khrustaleva, L.; Alexeev, D.; Zelenin, A.; Klimushina, M.; et al. Variation in copy number of Ty3/Gypsy centromeric retrotransposons in the genomes of Thinopyrum intermedium and its diploid progenitors. PLoS ONE 2016, 11, e0154241. [CrossRef] [PubMed]

74. Tang, Z.; Yang, Z.; Fu, S.; Yang, M.; Li, G.; Zhang, H.; Tan, F.; Ren, Z. A new long terminal repeat (LTR) sequence allows to identify J genome from JS and St genomes of Thinopyrum intermedium. J. Appl. Genet. 2010, 52, 31-33. [CrossRef] [PubMed]

75. Zhang, Y.; Fan, C.; Li, S.; Chen, Y.; Wang, R.; Zhang, X.; Han, F.; Hu, Z. The diversity of sequence and chromosomal distribution of new transposable element-related segments in the rye genome revealed by FISH and lineage annotation. Front. Plant Sci. 2017, 8. [CrossRef] [PubMed]

76. Xie, J.; Huo, N.; Zhou, S.; Wang, Y.; Guo, G.; Deal, K.; Ouyang, S.; Liang, Y.; Wang, Z.; Xiao, L.; et al. Sequencing and comparative analyses of Aegilops tauschii chromosome arm 3DS reveal rapid evolution of Triticeae genomes. J. Genet. Genom. 2017, 44, 51-61. [CrossRef] [PubMed]

77. Bergman, C.; Quesneville, H.; Anxolabéhère, D.; Ashburner, M. Recurrent insertion and duplication generate networks of transposable element sequences in the Drosophila melanogaster genome. Genome Biol. 2006, 7, 112. [CrossRef]

78. Wicker, T.; Guyot, R.; Yahiaoui, N.; Keller, B. CACTA Transposons in Triticeae. A diverse family of high-copy repetitive elements. Plant Physiol. 2003, 132, 52-63. [CrossRef]

79. Han, H.; Liu, W.; Lu, Y.; Zhang, J.; Yang, X.; Li, X.; Hu, Z.; Li, L. Isolation and application of P genome-specific DNA sequences of Agropyron Gaertn. in Triticeae. Planta 2016, 245, 425-437. [CrossRef]

80. Li, G.; Liu, C.; Wei, P.; Song, X.; Yang, Z. Chromosomal distribution of a new centromeric Ty3/Gypsy retrotransposon sequence in Dasypyrum and related Triticeae species. J. Genet. 2012, 91, 343-348. [CrossRef]

81. Baruch, O.; Kashkush, K. Analysis of copy-number variation, insertional polymorphism, and methylation status of the tiniest class I (TRIM) and class II (MITE) transposable element families in various rice strains. Plant Cell Rep. 2011, 31, 885-893. [CrossRef]

82. Wicker, T.; Gundlach, H.; Spannagl, M.; Uauy, C.; Borrill, P.; Ramírez-González, R.; De Oliveira, R.; Mayer, K.; Paux, E.; Choulet, F. Impact of transposable elements on genome structure and evolution in bread wheat. Genome Biol. 2018, 19, 103. [CrossRef] [PubMed]

83. Vicient, C.; Suoniemi, A.; Anamthawat-Jónsson, K.; Tanskanen, J.; Beharav, A.; Nevo, E.; Schulman, A. Retrotransposon BARE-1 and its role in genome evolution in the genus Hordeum. Plant Cell 1999, 11, 1769-1784. [CrossRef] [PubMed]

84. Kalendar, R.; Tanskanen, J.; Immonen, S.; Nevo, E.; Schulman, A. Genome evolution of wild barley (Hordeum spontaneum) by BARE-1 retrotransposon dynamics in response to sharp microclimatic divergence. Proc. Natl. Acad. 2000, 97, 6603-6607. [CrossRef] [PubMed]

85. Soleimani, V.; Baum, B.; Johnson, D. Quantification of the retrotransposon BARE-1 reveals the dynamic nature of the barley genome. Genome 2006, 49, 389-396. [CrossRef]

86. Wicker, T.; Keller, B. Genome-wide comparative analysis of Copia retrotransposons in Triticeae, rice, and Arabidopsis reveals conserved ancient evolutionary lineages and distinct dynamics of individual Copia families. Genome Res. 2007, 17, 1072-1081. [CrossRef]

87. Smýkal, P.; Kalendar, R.; Ford, R.; Macas, J.; Griga, M. Evolutionary conserved lineage of Angela-family retrotransposons as a genome-wide microsatellite repeat dispersal agent. Heredity 2009, 103, 157-167. [CrossRef]

88. Mahelka, V.; Kopecký, D.; Paštová, L. On the genome constitution and evolution of intermediate wheatgrass (Thinopyrum intermedium: Poaceae, Triticeae). BMC Evol. Biol. 2011, 11. [CrossRef]

89. SanMiguel, P.; Ramakrishna, W.; Bennetzen, J.; Busso, C.; Dubcovsky, J. Transposable Elements, Genes and Recombination in A 215-Kb Contig From Wheat Chromosome 5Am. Func. Integr. Genom. 2002, 2, 70-80. [CrossRef]

90. Kawaura, K.; Wu, J.; Matsumoto, T.; Kanamori, H.; Kagiri, S.; Ogihara, Y. Genomic analysis of the expressed $\alpha / \beta$-gliadin gene region in hexaploid wheat. In Proceedings of the 11th International Gluten Workshop, Beijing, China, 12-15 August 2012; pp. 21-26. 
91. Yang, Z.; Liu, C.; Feng, J.; Li, G.; Zhou, J.; Deng, K.; Ren, Z. Studies on genome relationship and species-specific PCR marker for Dasypyrum breviaristatum in Triticeae. Hereditas 2006, 143, 47-54. [CrossRef]

92. Li, X.; Lee, B.; Mammadov, A.; Koo, B.; Mott, I.; Wang, R. CAPS markers specific to Eb, Ee, and R Genomes in the tribe Triticeae. Genome 2007, 50, 400-411. [CrossRef]

93. Monte, J.; Flavell, R.; Gustafson, J. WIS 2-1A: An Ancient Retrotransposon in The Triticeae Tribe. Theor. Appl. Genet. 1995, 91, 367-373. [CrossRef] [PubMed]

94. Liu, Z.; Li, D.; Zhang, X. Genetic Relationships Among Five Basic Genomes St, E, A, B And D In Triticeae Revealed By Genomic Southern Andin Situhybridization. J. Integrat. Plant Biol. 2007, 49, 1080-1086. [CrossRef]

95. Wang, R.; Lu, B. Biosystematics and evolutionary relationships of perennial Triticeae species revealed by genomic analyses. J. Syst. Evol. 2014, 52, 697-705. [CrossRef]

96. He, R.; Chang, Z.; Yang, Z.; Yuan, Z.; Zhan, H.; Zhan, X.; Liu, J. Inheritance and mapping of powdery mildew resistance gene Pm43 introgressed from Thinopyrum intermedium into wheat. Theor. Appl. Genet. 2009, 118, 1173-1180. [CrossRef] [PubMed]

97. Bento, M.; Pereira, H.; Rocheta, M.; Gustafson, P.; Viegas, W.; Silva, M. Polyploidization As A Retraction Force in Plant Genome Evolution: Sequence Rearrangements in Triticale. PLoS ONE 2008, 3, e1402. [CrossRef] [PubMed]

98. Parisod, C.; Salmon, A.; Zerjal, T.; Tenaillon, M.; Grandbastien, M.; Ainouche, M. Rapid structural and epigenetic reorganization near transposable elements in hybrid and allopolyploid genomes in Spartina. New Phytol. 2009, 184, 1003-1015. [CrossRef]

99. Kroupin, P.Y.; Divashuk, M.G.; Karlov, G.I. Gene resources of perennial wild cereals involved in breeding to improve wheat crop (review). Sel'skokhozyaistvennaya Biol. 2019, 54, 409-425. [CrossRef]

100. Bernatzky, R.; Tanksley, S. Toward a saturated linkage map in tomato based on isozyme and random cDNA sequences. Genetics 1986, 112, 887-898.

101. LightCycler. Relative Quantification. Roche Applied Science Technical Note No. LC 13/2001. Available online: https://www.gene-quantification.de/roche-rel-quant.pdf (accessed on 18 December 2019).

102. Pfaffl, M. A new mathematical model for relative quantification in real-time RT-PCR. Nucleic Acids Res. 2001, 29. [CrossRef]

103. qPCR Hand Calculations. University of Puget Sound. Available online: https://studylib.net/doc/18190297/ qpcr-hand-calculations---university-of-puget-sound (accessed on 10 March 2019).

(C) 2019 by the authors. Licensee MDPI, Basel, Switzerland. This article is an open access article distributed under the terms and conditions of the Creative Commons Attribution (CC BY) license (http://creativecommons.org/licenses/by/4.0/). 